\title{
Teaching Chinese at the University LeVel in Serbia: Examples of Good Practices and Possibilities for Further DeVelopments
}

\author{
Ana M. JOVANOVIĆ \\ Faculty of Philology, University of Belgrade, Serbia \\ jovanna762004@yahoo.com
}

\begin{abstract}
The aim of this paper is to give a short overview of the current situation in the field of Chinese language teaching in Serbian formal education with a special emphasis on teaching Chinese at the university level. The Faculty of Philology of the University of Belgrade is one of the institutions with the longest tradition of teaching Chinese language as a major in the whole Balkan region, and in Serbia it is the only one where students can study Chinese at both the undergraduate and the graduate level. An elaborate curriculum, which includes courses on language, literature and culture, enables their students to gain a thorough insight in many aspects of ancient and modern China. Accordingly a large section of this paper is dedicated to presenting the teaching practices used at that institution, together with examples of some practical in-class methods. The paper also offers a short introduction to one private university in Serbia where Chinese language teaching has been carried out successfully. Finally it offers some ideas how teaching Chinese as a foreign language can be improved at all levels of study worldwide.
\end{abstract}

Keywords: Chinese language; L2 acquisition; Serbia; teaching practices; teaching materials

\section{Povzetek}

Namen članka je predstaviti trenutni položaj kitajščine $v$ ustanovah formalne izobrazbe $v$ Srbiji, še posebej na visokošolskih ustanovah. Filološka fakulteta (orig. Filološki fakultet) Univerze v Beogradu je ena izmed ustanov z najdaljšo tradicijo poučevanja kitajskega jezika na celotnem balkanskem področju in hkrati edina ustanova v Srbiji z dodiplomskim in podiplomskim študijem kitajščine kot samostojne študijske smeri. Natančno izdelan kurikulum, ki vključuje predmetnik jezika, literature in kulture, omogoča študentom vpogled $v$ številne vidike tradicionalne in moderne Kitajske. Posledično je članek posvečen predvsem praksam poučevanja na tej visokošolski ustanovi, od koder so vzeti primeri metod poučevanja, obenem pa predstavi tudi primer uspešne prakse poučevanja kitajskega jezika na eni izmed privatnih srbskih visokih šol. Ob koncu članek ponudi nekaj idej o načinih izboljšanja poučevanja kitajskega jezika, ki jih je moč uporabiti na vseh težavnostnih stopnjah ter po celem svetu.

Ključne besede: kitajščina; učenje drugega tujega jezika; Srbija; prakse poučevanja; učna gradiva

Acta Linguistica Asiatica, 8(1), 2018.

ISSN: 2232-3317, http://revije.ff.uni-lj.si/ala/

DOI: $10.4312 /$ ala.8.1.65-75 


\section{Introduction}

Teaching Chinese as a foreign language has long been a subject of research for many L2 acquisition experts and linguists both in China and abroad. These experts have been dedicated to finding the best teaching strategies, developing the best curriculum and teaching materials, and also educating generations of Chinese language teachers who would be able to satisfy the needs of foreign students who wish to study this Asian language.

According to Lu Jianming, the turning point in teaching Chinese as a foreign language occurred after the World Chinese Conference that took place in Beijing in July 2005, which marked the shift from teaching Chinese to foreigners in China (which was up to that date the focus of attention) to equally developing strategies for teaching Chinese to foreign students in China and abroad (Lu, 2008, p. 5). This shift in focus, however, by no means meant a decrease in the number of students who were coming to study Chinese in China, as this number showed a steady increase in the period from 2001 to 2010, the data gathered in the study carried out by Zhu Zhiping and Zhao Hongbo reveals. (Zhu \& Zhao, 2013, p. 27). This rather meant that while the number of foreign students in China grew, the number of people who wished to study Chinese language in their own countries also rose significantly. Indeed, when we take a look at the numbers presented in available papers and studies, it is not hard to conclude that Chinese has become one of the languages with the highest rate of attracting beginner students worldwide. This is certainly the situation in the United States, for example, where according to Zhang Kuan (2014) Chinese as an elective subject has the second largest growth rate among university students (as cited in Sheng, 2016, p. 616).

According to data from 2015, in Germany Chinese is taught as a foreign language in more than 300 primary and secondary schools, 36 universities, 14 Confucius Institutes and three Confucius classrooms (Yu, 2015, p. 127). In 2008, the number of state run high school students learning Chinese in England was more than seventy thousand, in a total of 500 schools, while in Russia there were fifteen thousand students studying Chinese in more than 150 state run elementary schools and high schools in 2007 (Zhang \& Qu, 2015, p. 15). These numbers undoubtedly show the increased interest in Chinese in the last decade.

As one of China's strategic partners in the Balkan region, Serbia is closely following the world-wide trend of increased interest in Chinese language and culture, the fact which can be seen from the large number of Chinese language classes opened in recent years. 


\section{Teaching Chinese at the pre-University Level in Serbia}

Chinese language is taught in Serbia at all four levels of formal education, namely: preschool education, elementary schools, high schools and universities. According to the "Confucius Institute in Belgrade work report" which has been published regularly since 2010 in the Confucius Institute in Belgrade's (in further text CIB) periodical named Confucius Institute in Belgrade Almanach ${ }^{1}$ (2010, 2011, 2012, 2013, 2014, 2015, 2016, 2017), and the latest information about the preliminary situation in the fall semester of the 2017/18 school year, the number of pre-school institutions in which Chinese classes were organized jointly with the CIB increased from one kindergarten in 2013 to three kindergartens in September 2017. The number of elementary schools that as a result of close collaboration with $\mathrm{CIB}$ started offering Chinese language as an optional course also rose, from two in 2014 to five in the fall semester of the 2017/18 school year. Due to the increased interest in China and Chinese, high schools were among the first institutions that sought to establish cooperation with CIB in order to offer their students language classes. Starting with one Belgrade high school in 2010, the current number of high schools collaborating with CIB is six, situated in three cities - Belgrade, Niš and Smederevo. It is also very important to note that in 2012 more than 90 classes in 31 schools in eight Serbian cities and districts were taught under the Memorandum on the promotion of Chinese language in elementary schools and high schools in Serbia which was signed between the Chinese and the Serbian government (Zhang \& Jin, 2016, p. 36, 37).

In two of the most prestigious Grammar schools in Serbia, the Philological Gymnasium in Belgrade and the Sremski Karlovci Gymnasium, Chinese language is an integral part of the curriculum approved by the Serbian Ministry of Education (Zhang \& Jin, 2016, p. 37). The Philological Gymnasium in Belgrade established Chinese language classes in 1995. Teaching Chinese as a second foreign language started in the Sremci Karlovci Gymnasium in 2012 (according to Zhang \& Jin, 2016, p. 37).

As for the teaching staff, elementary school and high school classes organized in collaboration with $\mathrm{CIB}$ are held by both local teachers and volunteer teachers from China, with the exception of kindergarten classes which are carried out only by the local Chinese teacher due to the fact that at such a young age most children do not speak any other language but their mother tongue. These local teachers are all Chinese language, literature and culture major graduates from the Faculty of Philology, University of Belgrade. Some of them have already completed Master of Teaching Chinese to Speakers of Other Languages program in China, while others are currently doing the above said MA program. For the latter, in order to successfully complete it,

\footnotetext{
${ }^{1}$ Confucius Institute in Belgrade Almanach is a periodical issued annually by $\mathrm{CIB}$, dedicated to publishing translations and original papers on Chinese culture, history, philosophy, language, literature, art etc. To date eight double-issues were published, the last one being issue XV/XVI for the year 2016 (published in 2017).
} 
half a year internship is required, which they do at those primary or secondary schools. After completion of the internship, they go back to China to defend their MA thesis. In the schools that offered Chinese language courses as part of the above mentioned Memorandum signed between the two governments, in 2012 language courses were held by 14 volunteer teachers from China sent by HANBAN (Zhang \& Jin, 2016, p. 37). As for the teaching materials, Chinese paradise (汉语乐园) is used in kindergartens and elementary schools while Happy Chinese (快乐汉语) and Learn Chinese with Me (跟我 学汉语) are used in high schools. Chinese language classes in elementary schools and high schools are carried out in accordance with the Curriculum for elementary school students and the Curriculum for high school students (Đin \& Jovanović, 2014; Đin, 2012), which were designed by CIB staff and local Chinese teachers.

\section{Teaching Chinese at the University Level in Serbia}

Due to the increased interest in China and Chinese language in the university student population, more and more universities in Serbia are offering Chinese language classes either as elective or noncredit courses in recent years. Chinese language is therefore taught at three state run universities and two private universities. The absolute leader in Chinese language teaching in Serbia is by far the University of Belgrade, which is at the same time the only one where students can major in Chinese language, literature and culture, and further continue their education at the MA and PhD levels. This paper will therefore introduce the Chinese Language, Literature and Culture studies at the Faculty of Philology, University of Belgrade, which has a forty-three year long tradition in teaching Chinese and China related courses. The second university that will be introduced is Singidunum University, as it is a good example of a private university that offers Chinese language courses. As this paper does not aim to be a comprehensive study of all institutions in which Chinese language can be learned, the focus will be put on these two with which I am mostly acquainted with.

At the Faculty of Philology, University of Belgrade, Chinese language has been taught since 1974, first as an elective course, and then since 1985 as the Chinese language and literature major (BZP, 2015, p. 7; Zhang \& Jin, 2016, p. 37). According to the "List of all students graduated from 1987 to June 2014" (BZP, 2015, p. 307-322) and Zhang \& Jin (2016, p. 37), the number of students that successfully completed their four-year study at the Department for Oriental Languages and Literatures majoring in Chinese Language and Literature totals around 400. The number of freshmen enrolled each year is 30 . This means that at any given time there are at least 120 undergraduate students, as well as a number of postgraduate students majoring in one of the three general modules (language, literature or culture studies) with a focus on China or Chinese related topics. There are seven local teachers currently employed at the Department for Oriental Languages and Literatures, Chinese Language, Literature and 
Culture major: one full professor, one associate professor, two docents, two senior lecturers, one assistant and one lecturer from China. Given its forty-three year long history, the Chinese Language, Literature and Culture major has an excellent and highly comprehensive curriculum that offers students a variety of subjects. The total number of Chinese or China related subjects at the undergraduate level is 38 , out of which 22 are language oriented ( 3 of which are dedicated to translation of Chinese texts), 6 are literature oriented while 10 are culture related (INFORMATOR, 2015, p. 171-173). Of course, given that language, literature and culture are very closely intertwined, and also closely related to history, philosophy, art and other spheres of human endeavors, the above given categories are made just for convenience, they are the product of my own rough division of subjects according to their general orientation and by no mean aim to be clear cut.

At the Faculty of Philology, according to the current undergraduate curriculum two to three language courses are assigned for each of the eight semesters. These language oriented subjects include intensive Chinese, spoken Chinese, Classical Chinese, grammar, listening and comprehension, practical Chinese reading, writing and written translation, as well as subjects belonging to the domain of linguistic culturology, such as those related to the Chinese writing system and idioms. All of these courses are aimed at jointly developing students' skills in both written and oral communication. For these purposes, and thanks to the expertise and very rich teaching experience of the Faculty's professors and lecturers, five textbooks were compiled to be used as the main textbooks for the intensive reading courses and the Classical Chinese course. The textbooks, which are published by the Faculty of Philology, are given in the table below:

Table 1: Chinese language textbooks published by the Faculty of Philology, University of Belgrade

INTENSIVE READING TEXTBOOKS

$1^{\text {st }}$ year Ma, Y. [马玉下], Jin, X. [金晓蕾], \& Pušić, R. [拉多萨夫·普西奇博士] (2004).

of study Kineski jezik 1: udžbenik kineskog jezika za prvu godinu studija [《汉语教程 1》]. Beograd: Filološki fakultet, NR Kina: Kancelarija za učenje kineskog jezika kao stranog.

$2^{\text {nd }}$ year Jin, Z. [金志刚], \& Pušić, R. [拉多萨夫·普西奇博士] (2004). Kineski jezik 2:

of study udžbenik kineskog jezika za drugu godinu studija [《汉语教程 2》]. Beograd: Filološki fakultet, NR Kina: Kancelarija za učenje kineskog jezika kao stranog.

$3^{\text {rd }}$ year Gu, Q. [顾清], \& Pavlović, M. [米尔娅娜.巴甫洛维奇硕士]. (2006). Kineski jezik of study 3: udžbenik kineskog jezika za treću godinu studija [《汉语教程 3》]. Beograd: Filološki fakultet, Kina: Kancelarija za učenje kineskog jezika kao stranog.

$4^{\text {th }}$ year Liu, W. [刘巍], Jin, X. [金晓蕾], \& Skrobanović, Z. [佐兰·斯克洛邦诺维奇硕士] of study (2009). Kineski jezik 4: udžbenik kineskog jezika za četvrtu godinu studija [《汉语 教程 4》] . Beograd: Filološki fakultet, Državna kancelarija za promociju kineskog jezika u svetu NR Kine. 
CLASSICAL CHINESE TEXTBOOK

$3^{\text {rd }}$ year Zhou, J. [周嘉向] (2004). Klasičan kineski jezik: udžbenik kineskog jezika za treću of study ${ }^{2}$ godinu studija [《古汉语教程》]. Beograd: Filološki fakultet.

Apart from these, other textbooks and additional materials are specially selected by the teachers in charge of oral Chinese, listening and comprehension, applied Chinese reading, writing and written translation and other courses. Particularly worth mentioning is a thorough overview of Chinese grammar divided into four different subjects in the first and second years of study, which focus separately on the basics of Chinese phonetics, morphology, lexicology and syntax. Apart from being very informative for the beginner learners, these are also very valuable preparatory courses for those who wish to continue their studies at the postgraduate level and dedicate themselves to the research of Chinese linguistics. Three translation courses are designed for the junior and senior students. More specifically, they are taught in the sixth, seventh and eight semesters of undergraduate studies. The aim of these subjects is to introduce the basics of written translation, and equal stress is put on the translation of both literary and non-literary texts. Classical Chinese Text is a course assigned to the senior students. Reading classical texts and translating them into contemporary Chinese allows students to understand the development of Chinese language more deeply, and it is crucial for the further improvement of their writing skills as well as their understanding of complex written language. ${ }^{3}$

As it was implied earlier, language cannot be mastered without the knowledge of culture and the understanding of civilization as a whole. That is why special attention at our Faculty is given to courses dedicated to various aspects of Chinese culture, philosophy, sinology, history, religion, film and the like. The topic of Chinese literature is divided into six different courses, focusing separately on the Classical, Modern and Contemporary era, with the most influential authors from each period selected and thoroughly introduced both theoretically and through their works.

At the offset of the postgraduate level, students can choose between three different modules: language, literature and culture, in accordance with which they further choose subjects. Currently, a number of China and Chinese related subjects are available for postgraduate students at any of the three modules: two are specially designed for students wishing to further their knowledge of Chinese linguistics, four for literature and two for culture. For example, one of the linguistic subjects at postgraduate level is dedicated to the historical development of the study and research of Chinese grammar, focusing primarily on the first grammars of Ma Jianzhong, Li Jinxi,

\footnotetext{
${ }^{2}$ Classical Chinese Text used to be taught in the $3^{\text {rd }}$ year of study, but is now taught in the first semester of the $4^{\text {th }}$ year.

${ }^{3}$ Information about specific subjects is obtained either through personal experience or conversations with the teachers in charge.
} 
Lü Shuxiang, Wang Li, Zhao Yuanren and other influential grammarians and linguists from the late $19^{\text {th }}$ century onward, while the second one puts its focus on morphemes, word formation, simple words, composition and derivation of words, phrases, types of phrases and idioms etc. These classes, for which students are required to read literature solely in Chinese, can provide postgraduates with the good basis for further individual research necessary for the successful completion of their MA thesis.

Those students who decide to dedicate themselves to the further research of language, literature or culture, can do that at the PhD level of study, where they can, among other courses, also chose one of four specific Chinese or China related subjects. For example, the linguistic course is aimed at introducing students to the theory of conceptual metaphors and its practical use in the research of Chinese lexicology or grammar related problems.

As was mentioned earlier, I will also shortly introduce one private university in Belgrade, Singidunum University that was the first private university to offer students the possibility of learning Chinese as a second foreign language. Chinese language classes are offered to students of different Faculties (for example Faculty of Business, Faculty of Tourism and Hospitality Management, Faculty of Informatics and Computing, Faculty of Technical Sciences etc.) as a second foreign language, to be studied for two or four years depending on the major. ${ }^{4}$ Contemporary Chinese 1 and 2 (textbook, workbook and character book) are used as the main teaching materials, with some additional resources (such as dictionaries, internet sources) used as auxiliary. ${ }^{5}$ Based on my professional opinion, with the amount of three classes per week, Singidunum University students can acquire a solid basis of spoken Chinese which can be very useful in their further professional careers and could also be further developed if they wished to undertake more advanced studies of language in the future. Currently there is only one docent teaching Chinese language at this university.

\section{Examples of Teaching Methodologies}

In this section I will describe two methods I am using in teaching of Intensive Chinese courses at the $3^{\text {rd }}$ and $4^{\text {th }}$ year of studies, which are based on my pedagogical experience and my research in the field of linguistics. The first example is related to the acquisition of new vocabulary. As students who have already grasped the most important grammar points in their $1^{\text {st }}$ and $2^{\text {nd }}$ year, the juniors' and seniors' main task is to expand their vocabulary, not only by simply memorizing new words, but also by

\footnotetext{
${ }^{4}$ Data is acquired from the Singidunum University official web site: https://singidunum.ac.rs/admission/ (last visit: October $\left.21^{\text {st }}, 2017\right)$, separately for each Faculty.

${ }^{5}$ Data is acquired from the Singidunum University official web site: http://predmet.singidunum.ac.rs/mod/page/view.php?id=3103 (last visit: October $21^{\text {st }}, 2017$ ).
} 
correlating those they already know with the newly acquired ones. In this sense, and as one type of exercise, instead of the students' mother tongue Chinese is used to explain a certain number of selected new words, because in that way the students are not only reminded of the words they already know, but also of the fact that the known words can be used to explain new ones. During the revision I encourage students to use the same strategy, that is, use the words they already know to try to explain the meaning of a certain new word. Students are however not required to learn by heart the Chinese explanations that they have been given, but instead to try to explain the meaning of a word using their own phrasing, or offering some hints in Chinese that would explain what this word is used for or when it is used. I believe that this practice can be beneficial for connecting the words they have already learned with the new ones in a vocabulary network in which the stimulus brought forth can motivate a number of related words. This method, however, is fully used only with the senior students, while its usage with juniors cannot be that extensive.

Another exercise I use is closely related to the very thorough explanations of words and phrases given in our textbooks. As can be seen from Table 1 above, our textbooks are written in both Serbian and Chinese, which means that we can use the benefits of both anywhere in the book. In other words, students are encouraged to read the Chinese explanations given in the textbooks (instead of just reading the Serbian ones, as they would naturally be inclined to do). The aim of this exercise is twofold: firstly, they gradually acquire a specific linguistics vocabulary that will enable them to use more Chinese resources (grammars, language learning manuals etc.) instead of just those written in English or any other language that they speak; secondly, it is a way of practicing reading explanatory texts which differ from the texts they are accustomed to. According to the feedback I have received so far, at the beginning students are not happy with the idea, but gradually, as they get over the initial difficulties, they say that it is actually not that hard. By the second semester, most of them are able to read these explanations without difficulties.

\section{Possibilities for Further Developments}

Teaching Chinese is rapidly becoming an integral part of formal education at all levels worldwide, so the need for Chinese language teachers is becoming greater than ever. In order to satisfy those needs, a new master program was established at Chinese universities in 2008, i.e. Master of Teaching Chinese to Speakers of Other Languages (汉语国际教育硕士) (ZCRY, 2016, p. 34). One idea for possible further developments is establishing similar MA programs in foreign countries, which would be solely dedicated to educating local Chinese language graduates wishing to work as Chinese language teachers in the future. That way the number of local teachers could be significantly increased, as those who for some reason are not able to go to China for 
MA studies (financial, personal reasons or others) would get the chance to specialize in this field. In addition, due to the specific nature of Chinese language itself, especially regarding its phonetics (pronunciation of certain consonants and vowels, tonal system), my firm belief is that the best results in teaching would be achieved if native Chinese teachers could - at all levels of education - work together with local teachers, which is a model that is still not widely applied. Given the shortage in Chinese language teachers worldwide, an exercise class with a native Chinese speaker once in two weeks could be considered as a solution for the initial phase. Finally, new developments in theoretical research should be more widely used in practice. The application of current research on the topic of conceptual metaphors, for example, could be used to facilitate the acquisition of new vocabulary at the higher levels of Chinese studies. ${ }^{6}$

\section{Concluding Remarks}

In light of the increasing popularity of Chinese language at all levels of education worldwide, Chinese language teachers from China and abroad should continue working together, exchanging ideas and sharing experiences and teaching practices that have been effective and useful - teaching each other and learning from each other, all at the same time - which is precisely the aim of this paper. By sharing the experiences and practices that represent the fruitful results of decades of hard work of devoted teachers, it invites colleagues from other institutions and universities worldwide to share their valuable insights and expertise. I believe that only through communication both with each other and with our students, we can adequately respond to the growing demands for Chinese language teachers and people very well versed in Chinese language.

\section{References}

Admission 2018/2019. Undergraduate academic studies. (n. d.) Singidunum University. Retrieved from https://singidunum.ac.rs/admission/

Đin, S. [金晓蕾] \& Jovanović, A. (Eds.). (2014). Nastavni plan i program kineskog jezika za učenike osnovnih škola. Beograd: Filološki fakultet.

Đin, S. [金晓蕾] (Ed.). (2012). Nastavni plan i program kineskog jezika za učenike srednjih škola. Beograd: Filološki fakultet, Institut Konfucije.

Institut Konfucije u Beogradu u 2010. (Confucius Institute in Belgrade). (2011). Almanah Instituta Konfucije u Beogradu, III/IV, Beograd: Filološki fakultet, 19-25 (35-41).

\footnotetext{
${ }^{6}$ For a detailed explanation of some of these methods see Li F. (2004); Jovanović, A. (2014).
} 
Jovanović, A. (2014). Similarities and differences in conceptualizing "heart" in Chinese and Serbian and their practical use in language teaching. In A. Küçükler \& H. İçen (Eds.), Studies on the Teaching of Asian Languages in the 21st Century (pp. 1-22). Newcastle upon Tyne: Cambridge Scholars Publishing. Retrieved from http://www.cambridgescholars.com/download/sample/60553

Li, F. [李福印]. (2004). Applied cognitive linguistics - Conceptual metaphor and image schemas in English learning [应用认知语言学——概念隐喻与意像图式在英语学习中的应用]. Beijing [北京]: Zhongguo wenshi chubanshe [中国文史出版社].

Lu, J. [陆俭明].(2008). Hanyu jiaoxue de xin bianhua, xin wenti, xin renwu, xin yishi [汉语教学 的新变化、新问题、新任务、新意识]. Jinan daxue Huawen xueyuan xuebao[暨南大学 华文学院学报], 3, 5-10.

Lu, J. [陆俭明].(2016). Hanyu guoji chuanbo zhong yixie daoxiangxing de wenti [汉语国际传 播中一些导向性的问题]. Yunnan shifan daxue xuebao (zhexue shehui kexue ban) [云南 师范大学学报（哲学社会科学版）],48 (1), 34-37.

Milenković, T. (Ed.). (2015). INFORMATOR Filološkog fakulteta Univerziteta u Beogradu. Beograd: Filološki fakultet.

O Institutu Konfucije u Beogradu [Confucius Institute in Belgrade]. (2010). Almanah Instituta Konfucije u Beogradu, I/II, Beograd: Filološki fakultet, 19-24 (31-36).

Pušić, R. (2014). Radni izveštaj Instituta Konfucije u Beogradu za 2013. godinu [Confucius Institute in Belgrade work report for the year 2013]. Almanah Instituta Konfucije $u$ Beogradu, IX/X, Beograd: Filološki fakultet, 19-23 (28-32).

Pušić, R. (2015). Izveštaj o radu Instituta Konfucije u Beogradu za 2014. godinu [Confucius Institute in Belgrade work report for the year 2014]. Almanah Instituta Konfucije $u$ Beogradu, XI/XII, Beograd: Filološki fakultet, 19-23 (28-32).

Pušić, R. (2016). Radni izveštaj Instituta Konfucije u Beogradu za 2015. godinu [Confucius Institute in Belgrade work report for the year 2015]. Almanah Instituta Konfucije $u$ Beogradu, XIII/XIV, Beograd: Filološki fakultet, 19-23 (30-34).

Pušić, R. (2017). Radni izveštaj Instituta Konfucije u Beogradu za 2016. godinu [Confucius Institute in Belgrade work report for the year 2016]. Almanah Instituta Konfucije $u$ Beogradu, XV/XVI, Beograd: Filološki fakultet, 19-22 (26-29).

Pušić, R. (Ed.). (2015). BZP: BISERI SA ZRNCIMA PIRINČA (Zbornik radova povodom 40 godina sinologije 1974-2014). Beograd: Filološki fakultet.

Radni izveštaj Instituta Konfucije u Beogradu za 2011. godinu [The Confucius Institute in Belgrade in 2011]. (2012). Almanah Instituta Konfucije u Beogradu, V/VI, Beograd: Filološki fakultet, 20-22 (26-29).

Radni izveštaj Instituta Konfucije u Beogradu za 2012. [Confucius Institute in Belgrade in 2012]. (2013). Almanah Instituta Konfucije u Beogradu, VII/VIII, Beograd: Filološki fakultet, 19-24 (32-36).

Silabus, kineski jezik 1 (n. d. ) Singidunum University. Retrieved from http://predmet.singidunum.ac.rs/mod/page/view.php?id=3103 
Yu, S. [俞松]. (2015). Deguo Hanyu jiaoxue xianzhuang fenxi yanjiu [德国汉语教学现状分析 研究]. Journal of HUBEI Correspondence University [湖北函授大学学报], 28 (19), $127,128,162$.

ZCRY (Zhuchiren yu) [主持人语]. (2016). Ben qi zhuanlan zhuti wei “Hanyu guoji jiaoyu” [本期 专栏主题为“汉语国际教育”]. Yunnan shifan daxue xuabao (zhexue shehui kexue ban) [ 云南师范大学学报（哲学社会科学版）], 48 (1), 34.

Zhang, J. [张婧], \& Jin, X. [金晓蕾]. (2016). Tan Saierweiya bentu Hanyu jiaoshi de peiyang [谈 塞尔维亚本土汉语教师的培养].OVERSEAS CHINESE EDUCATION [海外华文教育], 1, 3641.

Zhang, S. [张淑慧] \& Qu, J. [曲江川]. (2015). Guowai zhongxiaoxue Hanyu jiaoxue fazhan qushi yu guoji Hanyu shizi peiyang duice [国外中小学汉语教学发展趋势与国际汉语师 资培养对策]. Yunnan shifan daxue xuebao (duiwai Hanyu jiaoxue yu yanjiu ban) [云南师 范大学学报 (对外汉语教学与研究版) ], 13 (3), 15-21.

Zhu, Z. [朱志平] \& Zhao, H [赵宏勃]. (2013). Hanyu jiaoxue de guojihua jincheng - juji 21 shiji Hanyu shizi de peixun yu peiyang [汉语教学的国际化进程- - 聚焦 21 世纪汉语师资 的培训与培养].Beijing shifan daxue xuebao (shehui kexue ban) [北京师范大学学报（社 会科学版）], 2, 26-35. 